\title{
A refined graptolite biostratigraphy for the late Ordovician- early Silurian of central Wales
}

\author{
EDDIE BLACKETT, ALEX PAGE, JAN ZALASIEWICZ, MARK WILLIAMS, \\ BARRIE RICKARDS AND JEREMY DAVIES
}

Morphometric analysis of graptolites from the persculptus and acuminatus biozones of central Wales identifies four successive morphospecies of normalograptids. These graptolites can be used for biostratigraphical subdivision of these strata as follows: (a) an early persculptus Biozone interval containing broad forms with geniculate thecae that have the morphology of Persculptograptus persculptus with an early insertion point for the full median septum (theca $1^{1}$ ); (b) an supradjacent level of early persculptus Biozone age, with narrower, parallel-sided forms that have been reffered to as Normalograptus? cf. parvulus and a slightly later insertion point for the full median septum (theca $1^{2}$ ); (c) a third interval, encompassing the later part of the persculptus Biozone to the early acuminatus Biozone, with ?Normalograptus parvulus, which has the full median septum delayed to the level of theca 3-7; and (d) a younger interval, in the mid-acuminatus Biozone with Persculptograptus persculptus? specimens which do not display the median septum on its reverse side. These taxa can be used for refined biostratigraphy and correlation in the late Ordovician and early Silurian of central Wales. The progressive delay in the insertion of the median septum in these taxa may have wider application for the correlation of the interval immediately after the Hirnantian glacial maximum.

Stratigraphy, Hirnantian, Rhuddanian, evolution, graptolites.

Eddie Blackett, Jan Zalasiewicz [jaz1@le.ac.uk], Alex Page, Mark Williams [mri@le.ac.uk] Department of Geology, University of Leicester, University Road, Leicester, LE1 7RH, UK; Alex Page [aap30@esc.cam.ac.uk], Barrie Rickards, Department of Earth Sciences, 
University of Cambridge, Downing Street, Cambridge, CB2 3EQ, UK; Jerry Davies [jrdav@bgs.ac.uk] British Geological Survey, Keyworth, Nottingham, NG12 5GG, UK 
The latest Ordovician graptolite assemblages are of generally very low diversity (e.g. Koren' \& Bjerreskov 1999; Chen et al. 2000). Though more diverse assemblages occur on the Yangtze Platform, China, where highresolution biostratigraphic correlation is possible (e.g. Chen et al. 2005b), such high-resolution graptolite biostratigraphy has not previously been achieved in low-diversity faunas (cf. Chen et al. 2000). However, we use graptolites from central Wales to define four intervals in the latest Ordovician and earliest Silurian allowing high-resolution correlation within individual graptolite biozones.

The low-diversity late Ordovician graptolite fauna of central Wales contains abundant normalograptids including Persculptograptus persculptus (Elles \& Wood 1907) and Normalograptus? parvulus (Lapworth 1900). These taxa are commonly used for worldwide correlation of this interval (e.g. Koren' \& Bjerreskov 1999; Chen et al. 2000; Armstrong et al. 2005) when they flourished following the climatically-related end-Ordovician mass extinction (Chen et al. 2005a, b). 'Diplograpsus persculptus' was first recognised by Salter (1865), but was formally described and figured by Elles and Wood (1907, p. 257) to whom the species has been ascribed (Williams 1983; Zalasiewicz \& Tunnicliff 1994; Štorch \& Loydell 1996; Strachan 1997). Like P. persculptus, $N$ ? parvulus is also based on material from central Wales (Lapworth 1900; Zalasiewicz \& Tunnicliff 1994; Strachan 1997).

In central Wales, these graptolites show a progressive delay in the insertion of their median septum, first reported by K.A. Davies (1929) in assemblages of 'Glyptograptus persculptus'. The median septum is the partition between thecae on the left-side and right-side of the rhabdosome. The delay in its insertion is apparent on the reverse side of the rhabdosome (i.e. the opposite side to that which reveals the sicula), with the median septum being inserted proximally in stratigraphically early forms and more distally in stratigraphically later forms (K.A. Davies 1929). The obverse side of the rhabdosome, meanwhile, shows a complete median septum in all cases except rare, pathological specimens (e.g. Zalasiewicz \& Tunnicliff 1994, textfig. 5c); in stratigraphically late specimens the median septum forms a partial internal wall, not reaching the reverse side of the rhabdosome. K.A. Davies' (1929) obervations were later corroborated by Zalasiewicz \& Tunnicliff (1994), 
albeit on the basis of limited material. Such a delay in the insertion of the median septum has also been noted in other normalograptids (Waern 1948) and in Rhaphidograptus toernquisti (Hutt, 1974).

In this paper we describe how: (a) the insertion point of the medium septum in certain normalograptids can be used to define four successive intervals in the persculptus to mid acuminatus biozone strata in central Wales; and (b) how these can be used for refined correlation in sequences deposited in the aftermath of the Hirnantian glacial maximum. This glaciation reached its peak in the extraordinarius Biozone and continued into the early part of the persculptus Biozone (Sutcliffe et al. 2000; Chen et al. 2005b; Page et al. 2007).

\section{Geological setting}

The Late Ordovician (Hirnantian) to Early Silurian (Rhuddanian) succession of central Wales (Fig. 1A) consists of a lower, unfossiliferous sequence of slumped and disturbed strata, which is abruptly overlain by a bedded sequence in which graptolites are abundant. The disturbed rocks are included in the $\mathrm{Yr}$ Allt Formation; the bedded sequence constitutes the mudstonedominated Cwmere Formation and the laterally equivalent sandstone-rich units that replace it in some sections (see J.R. Davies et al. 1997 for definitions and synonyms). Hirnantian persculptus Biozone graptolites characterise the lower part of the Cwmere Formation (and its equivalents) with Silurian graptolite assemblages occurring above them at higher levels (acuminatus and younger biozones). The base of the Cwmere Formation includes a distinctive and widely recognised unit of burrow-mottled strata, called the Mottled Mudstone Member. Earliest persculptus Biozone graptolites occur close to the base of this member. They are preserved within thin beds of graptolitic mudstone known collectively as the 'persculptus Band' (Jones \& Pugh, 1916; J.R Davies et al. 1997), which can be traced across central Wales. The succession and its faunas are widely acknowledged to reflect eustatic changes in sea level linked to the end of the Hirnantian glacial maximum (e.g. Woodcock et al. 1996; Cherns et al. 2006; Page et al. 2007); 
the sharp base of the graptolite-bearing Mottled Mudstone Member is viewed as marking an abrupt post-glacial deepening event (Schofield et al. 2004) that continued during the deposition of the Cwmere Formation, when almost continuous sea floor anoxia was established (Woodcock et al. 1996; J.R. Davies et al. 1997).

Graptolite assemblages have been recovered from the Mottled Mudstone Member of the Cwmere Formation as well as overlying parts of this Formation and from laterally equivalent facies (such as the Cerig Gwynion Grits and Dyffryn Flags). These strata are well exposed in Cerig Gwynion Quarry near Rhayader (see Tunnicliff 1989; J.R. Davies et al. 1997; Zalasiewicz \& Tunnicliff 1994; Fig. 1D) and the associated Prysg stream section (Lapworth 1900; J.R. Davies et. al. 1997; Fig. 1B); the succession is also exposed at the Ystradffin section some $30 \mathrm{~km}$ to the south (K.A. Davies 1929). At the latter locality, the Mottled Mudstone Member is overlain by the Cwmere Formation in normal sequence (Fig 1C). However, at Cerig Gwynion Quarry and in the Prysg stream section the succession is more complex: the lower part of the Cwmere Formation, above the Mottled Mudstone Member, is replaced by sandstone-rich facies of the Caban Conglomerate Formation. The Caban Conglomerate Formation has variable vertical and lateral extent (J.R. Davies et. al. 1997); and in this area the Cerig Gwynion Grits facies of the Caban Conglomerate Formation is overlain by the Dyffryn Flags facies though the boundary between these two facies is gradational (Fig. 3). The biostratigraphic succession for this locality was studied in detail by Zalasiewicz \& Tunnicliff (1994). At all the localities, the graptolite-bearing strata comprise turbiditic mudstones and/or sandstones interbedded with subordinate hemipelagic layers (or hemipelagites). Hemipelagic layers have not been recognised in the underlying Yr Allt Formation.

\section{Collections}

At both Ystradffin and Cerig Gwynion, collections were obtained from two thin, closely-spaced laminated graptolite-bearing levels located close to the base of the Mottled Mudstone Member. These represent the local 'persculptus Band' 
(Fig. 2). At Cerig Gwynion Quarry and in the Prysg stream section, additional younger assemblages were also collected from facies of the Caban Conglomerate Formation (Fig. 3). Faunas from hemipelagites preserved between the thick sandstones of the Cerig Gwynion Grits are of persculptus Biozone age. The overlying, thinner-bedded Dyffryn Flags range from the persculptus Biozone into the basal Silurian acuminatus Biozone. Details of the exposures are as follows.

\section{Cerig Gwynion Quarry and Prysg stream section}

Cerig Gwynion Quarry is situated to the north of the A470 trunk road, west of Rhayader (Fig. 1B, D). Within the quarry six graptolite-bearing levels yielded hundreds of graptolites, including $P$. persculptus, $P$. persculptus?, ?N. parvulus and $N$ ? cf. parvulus. The exposures are located along a series of tracks and minor excavations through the quarry (Fig. 1D). Normalograptus medius, $N$. miserabilis and $N$. normalis have also been recorded from the quarry (see Tunnicliff 1989), but these are not treated further here. The two oldest graptolite-bearing levels are located at the base of the quarry, close to the main entrance (horizons $\mathrm{C} 1$ and $\mathrm{C} 2$; Figs 2A, 3); these correspond to the 'persculptus Band' of the Mottled Mudstone Member (J.R. Davies et al. 1997). These levels have a far greater abundance of graptolites than younger levels in the succession and the graptolites are often current-aligned within them. Younger levels (C3-C6; Fig. 3) are interspersed throughout a thick succession of turbidite sandstone and mudstone units; here, graptolite-bearing hemipelagic layers are difficult to locate and are individually thinner (because their vertical continuity is interrupted by turbiditic input) than the anoxic intervals of the 'persculptus band'. These horizons correspond to those identified in locality A of Zalasiewicz \& Tunnicliff (1994).

Adjacent to the A470, approximately $1.5 \mathrm{~km}$ to the north-east of Cerig Gwynion Quarry, is the Prysg stream section (Fig. 1B). The stream section locally exposes turbidite sandstones and mudstones with sporadic layers of laminated hemipelagite. This horizon (C7; Fig. 3) represents the mid to late acuminatus Biozone. It was collected by Lapworth (1900) and more recently 
by Zalasiewicz \& Tunnicliff (1994). No new material from this site was located in this study.

\section{Ystradffin}

Approximately $30 \mathrm{~km}$ to the southwest along the strike of the Ordovician/Silurian boundary is the remote section of Ystradffin, also referred to as Nant Y Caw (K.A. Davies 1929; see Fig. 1A). On a steep hillside, $1.5 \mathrm{~km}$ south of the Llyn Brianne reservoir, lies a large slate waste heap from which a small steeply-incised stream runs towards the road (Fig. 2). The exposure within the stream section is poor and sporadic. To the southeast, behind the waste heap, a small stream flows into a small, deep quarry, which is partly water-filled. The main section through the persculptus Biozone is on the northeast face of the quarry.

K.A. Davies (1929) placed the Ordovician/Silurian boundary at Ystradffin using lithological criteria; however, more recent biostratigraphic study has more accurately relocated the boundary in this section (see J.R Davies et al. 1997). K.A. Davies (1929) placed the Ordovician/Silurian boundary at the change from "doubly cleaved" shales of the Bala to the regularly cleaved shales of the Silurian. The Bala shales identified by K.A. Davies (1929) have subsequently been referred to the top of the $\mathrm{Yr}$ Allt Formation (J.R. Davies et al. 1997, table 6), and the overlying "regularly cleaved" shales, that K.A. Davies (1929) held to be Silurian, have since been referred to the Mottled Mudstone Member of the lowermost Cwmere Formation, which is nowadays regarded as of late Ordovician age (J.R. Davies et al. 1997). K.A. Davies (1929) observed that, approximately 3 feet $(0.90 \mathrm{~m})$ above the base of the "regularly cleaved" strata, 'G. persculptus' was present within a thin layer (the persculptus band). He stated that, some 7 feet $(2.3 \mathrm{~m})$ above this layer, there was a second thin layer with high concentrations of a more "robust" and longer morphotype of 'G. persculptus'.

We have re-examined this locality (Fig. 2) and located both of the graptolite-bearing layers identified by K.A. Davies (1929). However, our field observations show that the layer with "robust" persculptus (Y1) occurs stratigraphically below rather than above the layer with narrow specimens 
(Y2). We ascribe the discrepancy between our observations and those of K.A. Davies (1929) to his misidentification of bedding and cleavage at this locality (hence "doubly cleaved"), combined with minor slumping of the exposed rock mass. We consider that levels $\mathrm{Y} 1$ and $\mathrm{Y} 2$ are direct correlatives of levels $\mathrm{C} 1$ and $\mathrm{C} 2$ respectively.

\section{Material and Preservation}

Our field-collections yielded over 450 specimens, representing an unbiased sample of these graptolites. These specimens were typically part-obscured by rock when recovered; they have subsequently been excavated using needles. This is a painstaking process, but altogether over 300 suitably preserved specimens were prepared for analysis (see Table 2). These were dominantly near-proximal fragments or complete specimens with short stipes. For comparison we have also examined the specimens of K.A. Davies (1929). We also compared the lectotypes of $P$. persculptus and $N$ ? parvulus, which come from localities in central Wales and were designated by Williams (1983, p. 622) and Zalasiwicz \& Tunnicliff (1994, p. 705) respectively. All this material is held in the collections of the British Geological Survey at Keyworth, Nottingham.

The graptolites are preserved in laminated hemipelagites, mostly as partial- to full-relief pyrite steinkerns surrounded by denatured periderm (Fig. 4A-C, E-F). Pyritized specimens show well-preserved morphological detail, particularly fusellar banding (Fig. $4 \mathrm{C}, \mathrm{G}$ ) and the insertion of the median septum (Fig. 4D). In contrast, flattened specimens do not clearly show the median septum or fusellar banding (Fig. $4 \mathrm{H})$. All graptolites in this study have undergone conditions of deep burial diagenesis (J.R. Davies et al. 1997; Schofield et al. 2004), during which their preservation altered significantly (e.g. Page et al. 2005). Though periderm may undergo a considerable volume loss in maturation (AAP, unpublished observations), this has a negligible effect on any measurements taken here. Whilst pyritized graptolites may remain relatively undeformed during tectonism (e.g. Fig. 4F; Sudbury 1958) flattened graptolites may undergo significant distortion due to both collapse 
and tectonism (e.g. Sudbury 1958; Underwood 1992) and may not clearly preserve morphological features such as the insertion of the median septum (cf. Fig. 4G). Thus, only undeformed, pyritized specimens (e.g. Fig. 4A, C-D, $F)$ were included in the morphometric analysis.

To allow accurate measurement, the coating of phyllosilicate minerals that encases all the graptolites considered in this study was removed in preparation (see Fig $4 A-B, H$ ). The material from Cerig Gwynion Quarry is preserved in a weakly cleaved facies of high diagenetic grade (J.R. Davies et al. 1997) with only a slight tectonic distortion. However, the material from Ystradffin is preserved in a strongly cleaved facies of highest anchizone grade (J.R. Davies et al. 1997), and graptolites may show evidence of tectonic strain. At Ystradffin we only considered fully intact specimens in full relief (e.g. Fig 4F, cf. Fig. 4E), as diagenetic flattening may result in distortion (e.g. Sudbury 1958; Underwood 1992; Koren' \& Rickards 1996, p. 32). The graptolites are preserved parallel to bedding in all localities, and those within the 'persculptus band' often show current alignment suggesting that these intervals represent allochthonous faunas.

\section{Stratigraphic variation in graptolite morphotypes}

The latest Ordovician strata of central Wales are characterised by assemblages of morphologically similar graptolites with doubly sigmoidal, curved thecae and well-developed geniculae. Previous workers have tentatively assigned such graptolite taxa to the genus Normalograptus Legrand (1987) emend. Melchin \& Mitchell (1991). For example, Zalasiewicz and Tunnicliff (1994) recognised ' $N$ ? persculptus' and ' $N$ ? parvulus' in central Wales. These taxa are respectively larger and smaller forms that show a notable plasticity in degree of thecal curvature, genicular sharpness and waviness of the median septum. This variation is further accentuated by preservation and aspect differences. Both taxa have astogenetic pattern $\mathrm{H}$ (Mitchell 1987) and show differences from 'typical' normalograptid morphology (cf. Melchin and Mitchell 1991). With this in mind, Koren' \& Rickards (1996) proposed the monotypic genus Persculptograptus for graptolites with doubly 
sigmoidal thecae and an undulose median septum such as $P$. persculptus. In addition, Chen et al. (2005a, p. 252) noted that there is a distinctive species group in the latest Ordovician and earliest Silurian that shares these characters. Although Persculptograptus remains monotypic, it may be that this genus could include other taxa including some of those documented in this paper. However, as the focus of this paper is stratigraphic rather than taxonomic, we adopt the established generic names and refer the four morphotypes to ?N. parvulus, $N$ ? cf. parvulus, $P$. persculptus, and $P$. persculptus?.

The following parameters have been measured: dorsoventral width at thecal apertures 1, 3, 5 and 10; two-theca repeat distances (sensu Howe 1983) at theca 1, 3, 5, 10 and 15; position of the median septum's insertion on the reverse side; total rhabdosome and sicula length; distance from proximal end to the apertures of theca $1^{1}$ and theca $1^{2}$ apertures (see Loydell 1991 for illustrations of these descriptive terms). Additionally, the lengths of the nema and virgella were recorded where possible (although these did not show any significant trends). The full dataset is deposited at the British Geological Survey, Keyworth, Nottingham, in 1:50000 sheet file Rhayader (Sheet 179). The mean and standard deviation were calculated for dorsoventral widths, two-theca repeat distances (hereafter 2TRDS) and the rhabdosome length for each horizon, with individual localities positioned in stratigraphic order where applicable. In total over 300 well-preserved specimens were measured from the material described above (Table 2). Analysis of the material showed considerable variation between specimens at different stratigraphic levels, with four clear morphologies identified.

First interval: P. persculptus

The lowermost graptolite-bearing part of the 'persculptus Band' yields $P$. persculptus. This relatively broad graptolite with weakly geniculate thecae occurs at both Cerig Gwynion Quarry and Ystradffin ( $\mathrm{C} 1$ and $\mathrm{Y} 1$ respectively, Figs $2 \& 3$ ). These specimens have similar dimensions to the lectotype (Fig 5S; Table 1) and other specimens that have been referred to $P$. persculptus from elsewhere (Figs 3, 5A-E, 6; Table 1). The sharpness of the geniculum 
decreases distally. The insertion of the median septum on the reverse side is displayed in 58 specimens from $\mathrm{C} 1$ and in 15 specimens from $\mathrm{Y} 1$ and occurs as early as theca $1^{1}$ (Fig. 5A-E). These specimens are from the lower part of the persculptus Biozone.

Second interval: N? cf. parvulus

Specimens of $N$ ? cf. parvulus occur some $30 \mathrm{~cm}$ above level $\mathrm{C} 1$ at Cerig Gwynion Quarry, and a similar distance above level Y1 at Ystradffin, being the upper of the two graptolite-bearing levels in the 'persculptus band' (C2 and Y2 respectively, Figs $2 \& 3$ ). These are approximately parallel-sided, geniculate, narrow graptolites (Fig. 5F-M). These specimens closely resemble $N$ ? parvulus in outline and although they have widths comparable to specimens referred to this taxon, they have noticeably greater 2TRDs (Lapworth 1900; Zalasiewicz \& Tunnicliff 1994; Loydell et al. 2002; Chen et al. 2005a; Loydell 2007; see also Fig. 5Q \& Table 1). With this in mind we have refered it to $N$ ? cf. parvulus reflecting the relative uncertainties in both its genus and species. In the collection from $\mathrm{Y} 2$, there is a slight hint of bimodality in graptolite size (Fig. 6), with a small number of larger graptolites having sizes approaching those of $P$. persculptus. It is unclear whether this reflects a few rare, larger specimens of $N$ ? cf. parvulus or the presence of two species (i.e. N? cf. parvulus and $P$. persculptus). This uncertainty is in part due to the sample size. Regardless, 41 specimens from $\mathrm{C} 2$ and 39 specimens from Y2 specimens show the median septum being inserted on their reverse side at or just after theca $1^{2}$ (Fig. 5F-M). At this horizon (particularly at Cerig Gwynion Quarry), large numbers of siculae are evident on many of the bedding surfaces. These specimens are from the lower part of the persculptus Biozone, but this assemblage is from slightly higher strata than those of $\mathrm{C} 1$ and $\mathrm{Y} 1$.

Third interval: ?N. parvulus

Stratigraphically higher levels (C3-C6, Fig. 3) yield specimens assigned to ?N. parvulus. These are sub-parallel sided, geniculate and narrow graptolites with 
a similar outline to the specimens from $\mathrm{C} 2$, though they have generally smaller 2TRDs (Fig. 3; Table 1). Because of the sub-parallel sided nature of the rhabdosome and its slightly larger size compared to other specimens of N? parvulus (Lapworth 1900; Zalasiewicz \& Tunnicliff 1994; Loydell et al. 2002; Chen et al. 2005a; Loydell 2007; see also Fig. 5Q \& Table 1) we refer to these specimens as ?N. parvulus. At horizons C3 to C6, 16 specmens show the median septum inserted on the reverse side at or inbetween thecal pairs 3 and 7 with notable variation occurring within any one assemblage (Figs 3, 5N). These specimens range from the middle persculptus to lower acuminatus biozones.

Fourth interval: P. persculptus?

The stratigraphically highest graptolites in this study are assigned to $P$. cf. persculptus. These specimens occur in the Prysg section (C7, Fig. 3) and comprise broad and strongly geniculate specimens (Figs 3, 50-P). This horizon yields 11 specimens preserving their reverse aspect, but the median septum is not apparent in any of these graptolites representing a delay in insertion to greater than theca 15 (Figs 3,50-P). They are referred to as $P$. persculptus? because the size and shape of the rhabdosome differs slightly from the lectotype of $P$. persculptus and other specimens including those from horizons $\mathrm{C} 1$ and $\mathrm{Y} 1$ (cf. Fig 5A-E, R-S; Table 1). These specimens are from the middle acuminatus Biozone.

\section{A tool for correlation}

The graptolites we have examined from the persculptus to mid-acuminatus biozones interval in central Wales define at least four stratigraphic intervals. These occur within the post-glacial maximum late Ordovician and early Silurian sequence and these taxa can be used for regional correlation. The succession is summarised in Fig. 3 and comprises: (a) an early persculptus Biozone interval defined by broad forms with an early insertion point for the median septum on their reverse side (theca $1^{1}$ ); (b) an adjacent but younger 
level with narrower forms having a slightly later insertion point on their reverse side (theca $1^{2}$ ); (c) a third interval, encompassing the later part of the persculptus Biozone (i.e. above the level of horizons C2 and Y2) to the level of the early acuminatus Biozone with forms having the full median septum delayed to the level of theca 3-7; and (d) a younger interval, from the mid acuminatus Biozone with specimens that do not display the median septum on their reverse side. Though dorsoventral width and 2TRD may be diagnostic if several tens of specimens are measured, the principal stratigraphic tool we have used in defining these intervals is the delay in the insertion point of the medium septum.

This subdivision of the persculptus and acuminatus biozones can be used to refine correlation of late Ordovician and early Silurian (Cwmere Formation) strata through central Wales (as suggested by K.A. Davies 1929). In the Wye Valley, Zalasiewicz and Tunnicliff (1994) identified 'N.? persculptus' which lacked a median septum on its reverse side indicative of the acuminatus Biozone, and equivalent to the uppermost interval in the scheme we present above. Recent mapping by the British Geological Survey for the Llanidloes Sheet has identified a new section through the Mottled Mudstone Member (including the 'persculptus Band') into the succeeding Cwmere Formation in the Hafren Forest (Grid Reference SN 8415 8990). Here, anoxic laminated hemipelagites present in the lower $2 \mathrm{~m}$ of the Mottled Mudstone Member yield "robust" $P$. persculptus with dorsoventral widths at theca $1^{1}$ exceeding $1 \mathrm{~mm}$, and $1.5 \mathrm{~mm}$ at theca 5 , and with an early insertion of the median septum (from the level of theca 1). This represents a level equivalent to horizons $\mathrm{C} 1$ and $\mathrm{Y} 1$ at Cerig Gwynion Quarry and Ystradffin. Meanwhile, the uppermost part of this anoxic unit yields smaller parallel-sided specimens with a similar outline to $N$ ? cf. parvulus, which have a typical dorsoventral width of $1.1 \mathrm{~mm}$ distally, and an early insertion point for the median septum at theca $1^{2}$. This level is equivalent to horizons $\mathrm{C} 2$ and $\mathrm{Y} 2$ (Fig. 3). Above the bioturbated facies of the Mottled Mudstone Member in Hafren Forest, the lower metre of the succeeding Cwmere Formation yields "robust" specimens (dorsoventral width up to $1.5 \mathrm{~mm}$ distally), which again show an early insertion point for the median septum. This level is almost certainly lower in the succession than horizons C3 and C4 at Cerig Gwynion 
Quarry. These collections, made by the BGS independently of those at Cerig Gwynion Quarry and Ystradffin, confirm that these successive morphological changes can be used for refined correlation of this interval throughout central Wales. Extensive Hafren Forest exposures in the graptolitic Cwmere Formation overlying the Mottled Mudstone Member provide potential to investigate graptolites for strata equivalent to the interval between levels C2 and C3 at Cerig Gwynion Quarry.

Further subdivision of these biozones may possibly be achieved by comparing the above data with the occurence of potentially diagnostic taxa from the Cerig Gwynion Quarry and Prysg succession (see Zalasiewicz \& Tunnicliff 1994, Text-figs 1 \& 3). Zalasiewicz and Tunnicliff (1994) recognised the graptoltes $G$ ? avitus, $A$. ascensus and $P$. acuminatus in this sucession (Fig. 3). These taxa have been employed in biostratigraphy elsewhere, with the first appearance of $A$. ascensus and $P$. acuminatus used to define the base of their eponymous biozones (e.g. Chen et al. 2000) and G? avitus occurring in middle persculptus to lower acuminatus biozone strata in Scotland (Williams 1983). In the Cerig Gwynion Quarry succession the first appearances of G? avitus and ?N. parvulus occur at horizon C3 (middle persculptus Biozone), whilst the first appearance of $A$. ascensus is at horizon C5 (upper persculptus Biozone) where ?N. parvulus also occurs. The last appearance of ?N. parvulus and $A$. ascensus is at horizon C6 (lower acuminatus Biozone), which also sees the first appeareance of $P$. acuminatus. Though it would be premature to divide the persculptus Biozone into separate persculptus and ascensus Biozones based on a single section, detailing the occurance of these taxa at this locality may be of use for comparison with other successions in central Wales (e.g. the Hafren Forest section described above).

Whilst N? parvulus is known from both Ordovician and Silurian strata, $P$. persculptus is only definitely known from Ordovician strata (Loydell 2007). Thus the occurrence of $P$. persculptus? in the acuminatus Biozone in the Prysg section may be of interest.

\section{Graptolite evolution and the median septum}


Distinguishing between $\mathrm{N}$ ? parvulus and $\mathrm{P}$. persculptus

The graptolites N.? parvulus (Lapworth 1900, p. 132) and P. persculptus (Elles \& Wood 1907, p. 257) bear a striking resemblance to each other, so much so that these species have at times been conflated (see synonymy in Chen et al. 2005a, p. 266, for example). This might in part reflect the poor preservation of their lectotypes and lack of illustrated topotype material for either taxon (Williams 1983; Zalasiewicz \& Tunnicliff 1994) meaning that the morphological variation of the type population remains uncertain. Both $P$. persculptus and N.? parvulus are based on late Ordovician material from central Wales, and the two types are refigured here for comparison (Fig. $5 Q$, S). The type of $N$ ? parvulus has an incomplete proximal end (Fig. 5Q) and does not extend beyond its fifth thecal pair. The type of $P$. persculptus is preserved as a distally incomplete compression (Fig. 5R), however lying adjacent to the type is a well-preserved topotype suitable for measurement (Fig. 5S). These taxa have been recognised worldwide with N.? parvulus displaying closer thecal spacing and narrower dorsoventral widths than $P$. persculptus (e.g. Williams 1983; Koren' \& Rickards 1997; Loydell et al. 2002; Chen et al. 2005b; Loydell 2007; Table 1). However, these specimens occupy a morphological continuum based on the measurements of widths and 2TRDs for proximal thecae, and Zalasiewicz \& Tunnicliff (1994, p. 705) suggested that $N$ ? parvulus and $P$. persculptus may represent "end member[s] of a single, variable species."

Recent work has led to a slightly revised concept of $N$ ? parvulus, with several authors diagnosing it on its distal morphology (e.g. Loydell 2002, 2007; Chen et al. 2005a). Loydell (2007, Text-fig. 9) distinguished ' $N$. parvulus' from ' $N$. persculptus' on the basis of its 2TRD at theca $10^{1}$, though even these specimens display a notable ovelap in their dorsal ventral widths and more proximal morphology. Table 1 compares the range of variation in our material with type specimens of $N$ ? parvulus (Lapworth 1900) from $P$. persculptus (Elles \& Wood 1907) and the material assigned to 'N. parvulus' and 'N. persculptus' by Loydell (2007), the dimensions of which seem typical of other material assigned to these taxa (e.g. Hutt 1974; Williams 1993; Chen 
et al. 2005a). Though our specimens are usually only complete to the sixth or seventh thecal pair, there a few longer specimens amongst the collection enabling a more accurate comparison with occurences of the taxa reported elsewhere (Table 1). Any ambiguity in diffentiating these taxa may be further reduced if topotype populations were better known; however, the topotype material of $P$. persculptus is poorly preserved (Williams 1983) and only a single specimen is known from the type locality of $N$ ? parvulus (Zalasiewicz \& Tunnicliff 1994).

?N. parvulus and P. persculptus: one or two lineages?

This study shows that there is considerable variation in the morphotype of these normalograptids with time, showing an alternation between broader and narrower forms. These may represent either one or two lineages. A single lineage united by the progressive delay in the median septum comprising $P$. persculptus -?N. parvulus-N.? cf. parvulus-P. cf. persculptus would require considerable morphological plasticity with regard to graptolite size. Conversely, our material could perhaps represent two lineages, a narrower $N$ ? cf. parvulus-?N. parvulus lineage and a broader $P$. persculptus- $P$. persculptus? lineage. This scenario would require both lineages to undergo parallel evolution with regard to the median septum and display a 'see-saw' pattern of abundance through time. Though the precise evolutionary relationship of these taxa is as yet uncertain, the progressive delay in insertion of the median septum in these taxa is unambiguous.

Delayed insertion of the median septum

Progressive delay in the insertion point of the median septum is also known to occur within other lineages of biserial graptolites and may provide a mechanism for the evolution of aseptate forms. In Rhaphidograptus toernquisti (see Rickards 1970, Hutt 1974, p. 53) the median septum occurs at thecal pair 9 in specimens from the early Aeronian (triangulatus and magnus Biozones) and at thecal pairs 9-11 in stratigraphically younger 
specimens (argenteus Biozone). Similar delay in the median septum was recorded in the early Silurian Baltic taxa 'Climacograptus scalaris transgrediens $\mathrm{n}$. var. forma ó- $\delta$ ' and 'C. medius' (Waern 1948, pp. 449, 454). Waern noted a progressive delay in the insertion point of the median septum (on the reverse side) from between theca $2^{1}$ and $3^{1}$ to between theca $3^{1}$ and $4^{1}$, and subsequently to thecal pair $4-5$. We are not aware of a graptolite lineage in which the insertion point of the median septum becomes more proximal at stratigraphically higher levels.

A complete median septum divides the rhabdosome into two portions, forming the dorsal wall of two separately growing stipes. The point of insertion of the full median septum marks the position of the dicalyc and the point at which one stipe with alternately growing thecae divides into two. However, certain cryptoseptate species exist in which these separately growing stipes were connected through a series of foramina that punctuated an otherwise complete median septum (e.g. Fortey 1971, Text-fig. 4). The median septum may have also served to strengthen the rhabdosome. It inserts in the obverse and reverse walls of the rhabdosome but does not protrude distally beyond the rhabdosome, consistent with it serving as a cross-brace and probably precluding a hydrodynamic function. The creeping tubes of modern pterobranchs consist of a series of fusellae-like increments that readily detach from each other given even the mildest perturbation (AAP unpublished observations). As noted above, the reverse section of the median septum is lost or proximally atrophied in several taxa, and is not secondarily regained. If it served to strengthen the rhabdosome, its loss could perhaps be compensated for by the secretion of cortical bandages, which tend to have a criss-cross habit oblique to fusellae (Crowther 1981), and may provide an alternative means of strengthening the partially septate portion of the rhabdosome.

\section{Conclusions}

Morphometric analysis of graptolites from the latest Ordovician through earliest Silurian of central Wales identifies four successive persculptus/parvulus-like morphologies, revealed particularly by changes in 
the insertion point of the median septum. The progressive delay in the insertion of the median septum suggests these taxa underwent directional microevolution; however, it is as yet unclear whether they represent either one or two lineages. These taxa can be used for refined stratigraphic correlation with a sub-graptolite biozone resolution. Presently, such patterns have not been recorded when these taxa occur in other Avalonian sequences (e.g. Hutt 1974) or elsewhere, perhaps reflecting the scarcity of numerous and wellpreserved specimens in these collections.

Acknowledgements We thank Mike Howe and Louise Neep (BGS) for loan of fossil material, David Loydell (Portsmouth) for helpful discussion of these taxa, and Rob Wilson, Rod Branson and Colin Cunningham for technical support at Leicester. We also acknowledge helpful comments from Mike Melchin (St. Francis Xavier University) and an anonymous reviewer for their constructive comments on an earlier version of this manuscript. Jerry Davies publishes with the permission of the Executive Director, British Geological Survey (NERC). Cambridge Earth Sciences contribution number ES.9052.

\section{References}

Armstrong, H.A., Turner, B.R., Makhlouf, I.M., Weedon, G.P., Williams, M., Smadi, A.A. \& Salah, A.A. 2005: Origin, sequence stratigraphy and depositional environment of an upper Ordovician (Hirnantian) deglacial black shale, Jordan. Palaeogeography, Palaeoclimatology, Palaeoecology 220, 273-289.

Chen Xu, Rong Jiayu, Mitchell, C.E., Harper, D.A.T., Fan Jun-Xuan, Zhan Renbin, Zhang Yuandong, Li Rongyu \& Wang Yi 2000: Late Ordovician to earliest Silurian graptolite and brachiopod biozonation from the Yangtze region, South China, with a global correlation. Geological Magazine 137, 623-650. 
Chen Xu, Fan Jun-Xuan, Melchin, M.J. \& Mitchell, C.E. 2005a: Hirnantian (Latest Ordovician) graptolites from the Upper Yangtze region, China. Palaeontology 48, 235-280.

Chen Xu, Melchin, M.J., Sheets, H.D., Mitchell C.E. \& Fan Jun-Xuan 2005b: Patterns and Processes of Latest Ordovician Graptolite Extinction and Recovery based on data from South China. Journal of Paleontology 79, 842-861.

Cherns, L., Cocks, L.R.M., Davies, J.T., Hillier, R.D., Waters, R.A. \& Williams, M. 2006: Silurian: the influence of extensional tectonics and sea-level changes on sedimentation in the Welsh Basin and on the Midland Platform. In Brenchley, P.J. and Rawson, P.F. (eds), The Geology of England and Wales, $2^{\text {nd }}$ Edition, 75-102. Geological Society Publishing House, Bath.

Crowther, P.R. 1981: The fine structure of graptolite periderm. Special Papers in Palaeontology 26.

Davies, J.R., Fletcher, C.J.N., Waters, R.A., Wilson, D., Woodhall, D.G. \& Zalasiewicz, J.A. 1997: Geology of the country around Llanilar and Rhayader. Memoir of the British Geological Survey, Sheets 178 and 179 (England and Wales).

Davies, K.A. 1929: Notes on the graptolite faunas of the Upper Ordovician and Lower Silurian. Geological Magazine 66, 1-27.

Elles, G.L. \& Wood, E.M.R. 1907: A monograph of British Graptolites. Part 6. Monograph of the Palaeontographical Society 6, 217-272.

Fortey, R.A. 1971: Tristichograptus, a triserial graptolite from the Lower Ordovician of Spitsbergen. Palaeontology 14, 188-199.

Howe, M.P.A. 1983: Measurement of thecal spacing in graptolites. Geological Magazine 120, 635-638.

Hutt, J.E. 1974: The Llandovery graptolites of the English Lake District. Part 1. Monograph of the Palaeontographical Society 128, 1-56.

Jones, O.T \& Pugh, W.J. 1916: The geology of the district around Machynllech and the Llyfnant Valley. Quarterly Journal of the Geological Society of London 71, 343-385. 
Koren', T.N., \& Bjerreskov, M. 1999. The generative phase and the first radiation event in the Early Silurian monograptid history. Palaeogeography, Palaeoclimatology, Palaeoecology 154, 3-9.

Koren', T.N. \& Rickards, R.B. 1996: Taxonomy and evolution of Llandovery biserial graptoloids from the southern Urals, western Kazakhstan. Special Papers in Palaeontology 54.

Koren', T.N., Mikhaylova, N.F. \& Tzai, D.T. 1980. Class Graptolithina. Graptolites In Apollonov, M.K., Bandaletov, S.M. \& Nikitin, I.F. (eds). The Ordovician-Silurian boundary in Kazakhstan. Nauka, Kazakh. SSR Publishing House, Alma Ata, 121-214. [In Russian]

Lapworth, H. 1900: The Silurian sequence of Rhayader. Quarterly Journal of the Geological Society of London 56, 67-137.

Legrand, P. 1987: Modo de desarrollo del suborden Diplograptina (Graptolithina) en el Ordovicico Superior y en el Silurico. Revista Española de Paleontología 2, 59-64.

Loydell, D.K. 1991: Upper Aeronian and Lower Telychian (Llandovery) graptolites from western mid-Wales. Part 1. Monograph of the Palaeontographical Society 146, 1-55.

Loydell, D.K. 2007: Graptolites from the Upper Ordovician and Lower Silurian of Jordan. Special Papers in Palaeontology 78.

Loydell, D.K., Mallett, A.M., Mikulic, D.G., Klussendorf, J. \& Norby, R.D. 2002: Graptolites from near the Ordovician-Silurian boundary in Illinois and lowa. Journal of Paleontology, 76, 134-137.

Melchin, M.J. \& Mitchell, C.E. 1991: Late Ordovician extinction in the Graptoloidea. In Barbes, C.R. \& Williams, S.H. (eds). Advances in Ordovician geology. Geological Survey of Canada, Paper 90-9, 143-156.

Mitchell, C.E. 1987: Evolution and phylogenetic classification of the Diplograptacea. Palaeontology 30, 353-405.

Page, A., Wilby, P. \& Zalasiewicz, J. 2005: Clay-organic interactions in graptolitic mudrocks. Palaeontological Association Newsletter 60, 53.

Page, A., Zalasiewicz, J., Willams, M. \& Popov, L.E. 2007: Were transgressive black shales a negative feedback modulating glacioeustacy in the Early Palaeozoic Icehouse. In Williams, M., Haywood, A., Gregory, J. \& Schmidt, D. (eds) Deep time perspectives on climate change, 123- 
156. The Micropalaeontological Society. Geological Society Publishing House, Bath.

Rickards, R.B. 1970: The Llandovery (Silurian) graptolites of the Howgill Fells, northern England. Monograph of the Palaeontolographical Society 123.

Salter, J.W. 1865: In Huxley, T.H. \& Etheridge, R.A. (eds) A catalogue of the collection of fossils in the Museum of Practical Geology, London.

Schofield, D.I., Davies, J.R., Waters, R.A., Wilby, P.R., Williams, M. \& Wilson, D. 2004: Geology of the Builth Wells district - a brief explanation of the geological map. Sheet Explanation of the British Geological Survey, 1:50000 Sheet 196 Builth Wells (England and Wales). Keyworth, Nottingham: British Geological Survey.

Štorch, P. \& Loydell, D.K. 1996: The Hirnantian graptolites Normalograptus persculptus and 'Glyptograptus' bohemicus: Stratigraphical consequences of their synonymy. Palaeontology 39, 869-881.

Strachan, I. 1997: A bibliographic index of British Graptolites (Graptoloidea). Part 2. Monograph of the Palaeontographical Society 151, 41-155.

Sudbury, M. 1958: Triangulate monograptids from the Monograptus gregarious Zone (lower Llandovery) of the Rheidol Gorge (Cardiganshire). Philosophical transactions of the Royal Society of London, Series B 281, 485-555.

Sutcliffe, O.E., Dowdeswell, J.A., Whittington, R.J., Theron, J.N. \& Craig, J. 2000: Calibrating the Late Ordovician glaciation and mass extinction by the eccentricity of Earth's orbit. Geology 28, 967-970.

Tunnicliff, S.P. 1989: Graptolites associated with the Cerrig Gwynion Grits. British Geological Survey Technical Report, Stratigraphy Series, $\mathrm{WH} / 89 / 188 \mathrm{R}$.

Underwood, C.J. 1992: The preservation and deformation of graptolites. Palaios 7, 178-186.

Waern, B. 1948: The Silurian strata of the Kullatorp Core. In Waern, B., Thorslund, P. \& Henningsmoen, G. Deep boring through Ordovician and Silurian strata at Kinnekulle, Vestergötland. Bulletin of the Geological Institutions of the University of Uppsala 32, 433-474.

Woodcock, N.H., Butler, A.J., Davies, J.R. \& Waters, R.A. 1996: Sequence stratigraphical analysis of late Ordovician and early Silurian depositional 
systems in the Welsh Basin: a critical assessment. In: Hesselbo, S.P. \& Parkinson, D.N. (eds). Sequence stratigraphy in British Geology. Special Publication of the Geological Society of London 103, 197-208.

Williams, S.H. 1983: The Ordovician-Silurian boundary graptolite fauna of Dob's Linn, Southern Scotland. Palaeontology 26, 605-639.

Zalasiewicz, J.A. \& Tunnicliff, S.P. 1994: Uppermost Ordovician to Lower Silurian graptolite biostratigraphy of the Wye valley, central Wales. Palaeontology 37, 695-720. 
Fig. 1. Geographical location of the graptolite collections from central Wales: A, distribution of Llandovery strata in Wales; B, D, Cerig Gwynion Quarry and Prysg; C, Ystradffin.

Fig. 2. Rock exposures of the "persculptus band": A, Cerig Gwynion Quarry; $B$, Ystradffin (photograph taken from near waterfall looking east). For position of sampled horizons see Fig. 1.

Fig. 3. Stratigraphic position of horizons $\mathrm{C} 1$ to $\mathrm{C} 7$ within the Cwmere Formation at the Cerig Gwynion Quarry and Prysg sections. Summary morphological and morphometric information for graptolites recovered from these horizons provided as means plus or minus one standard deviation for measurements of 2TRD (sensu Howe 1983) and dorsoventral width (DVW). The precise rock interval between horizon C6 (the uppermost horizon in Cerig Gwynion Quarry) and C7 (Prysg) cannot be determined. Biostratigraphy, lithostratigrahy and first appearance datums (FADs) of biostratigraphically important graptolites as Zalasiewicz \& Tunnicliff (1994)

Fig. 4. Preservation of graptolites from central Wales. A-B, E-F are backscattered electron micrographs, C, G are secondary electron micrographs, and $\mathrm{D}, \mathrm{H}$ are light micrographs of specimens whitened by coating with ammonium chloride. A-B, graptolites from horizon $\mathrm{C5}$, oblique and orthogonal profiles at $x 33$ and $x 36$. The 'white phase' is a pyrite or sphalerite steinkern and the 'light' and 'mid grey'-phases are phyllosilicate "strain fringes". C-D, pyritised graptolites from Cerig Gwynion Quarry, showing preservation of fusellar increments in both kerogenised periderm, charcoal grey, and pyrite steinkern, light grey (C) and in pyrite (D), magnifications $x 23$ and $x 14$. E-F, graptolites from horizon $Y 1$, orthogonal profiles through undistorted and tectonically deformed specimens at x26 and $\mathrm{x} 38$, phases are as $A \& B$, except the darkest grey phase is a silica strain fringe. G, pyritised graptolite with preservation of fusellae in kerogenised periderm, and fibrous phyllosilicate "strain fringes", magnification, x41. H, pyritised and diagenetically flattened graptolites, $x 10$. 
Fig. 5. Graptolites from the latest Ordovician and earliest Silurian of central Wales. A-E, R-S, Persculptograptus persculptus (Elles \& Wood), including topotype (R) and lectoptype as designated by Williams (1983) (S); F-M, Normalograptus? cf. parvulus (Lapworth); N, ?Normalograptus parvulus $(\mathrm{H}$. Lapworth); O-P, Persculptograptus persculptus (Elles \& Wood); Q, Normalograptus? parvulus (Lapworth) lectotype as designated by Zalasiewicz \& Tunnicliff (1994). A, EJB412, horizon C1. B, EJB408, horizon C1. C, EJB953, horizon Y1. D, EJB958, horizon Y1. E, EJB963, horizon Y1. F, JZ4681, horizon C2. G, JZ4890, horizon C2. H, JZ4877, horizon C2. I, JZ4858, horizon C2. J, EJB412, horizon C2. K, EJB129, horizon Y2. L, M, EJB97, horizon Y2. N, JZ4761, horizon C5. O, DJ8812, horizon C7. P, JZ417, horizon C7. Q, BU 1293, Gwastaden, Rhayader, persculptus or acuminatus Biozone (see Zalasiewicz \& Tunnicliff 1994). R-S, GSM11782, Ogofau, Pumpsaint, persculptus or acuminatus Biozone (see Williams 1983). A-B, H-J, N-P, Cerig Gwynion Quarry and Prysg stream section. C-E, K-M, Ystradffin. Specimens prefixed EJB, JZ, DJ and GSM are in the collections of the British Geological Survey, Keyworth. BU is Birmingham University, Lapworth Museum. A-Q x10, R-S x5.

Fig. 6. Dorsoventral width (left column) and 2TRD (sensu Howe 1983) for specimens from Cerig Gwynion Quarry (horizons C1, C2) and Ystradffin (horizon Y2). Using these criteria, the range of variation between parvulus-like and persculptus-like specimens in our collections is continuous. However, the insertion point of the median septum and overall shape of the rhabdosome, in conjunction with dorsoventral width, can be used to define four stratigraphically discrete morphotypes as noted in the text.

Table 1. Total range of variation in our specimens compred to the types of $N$ ? parvulus (Lapworth 1900) and P. persculptus (Elles \& Wood 1907) and specimens assigned to 'N. persculptus' and 'N. pavulus' in Loydell (2007, pp. 41-44, Text-fig 9) . Abbreviations as Fig. 3.

Table 2. Measured specimens from Cerig Gwynion, Prysg and Ystradffin sections. 

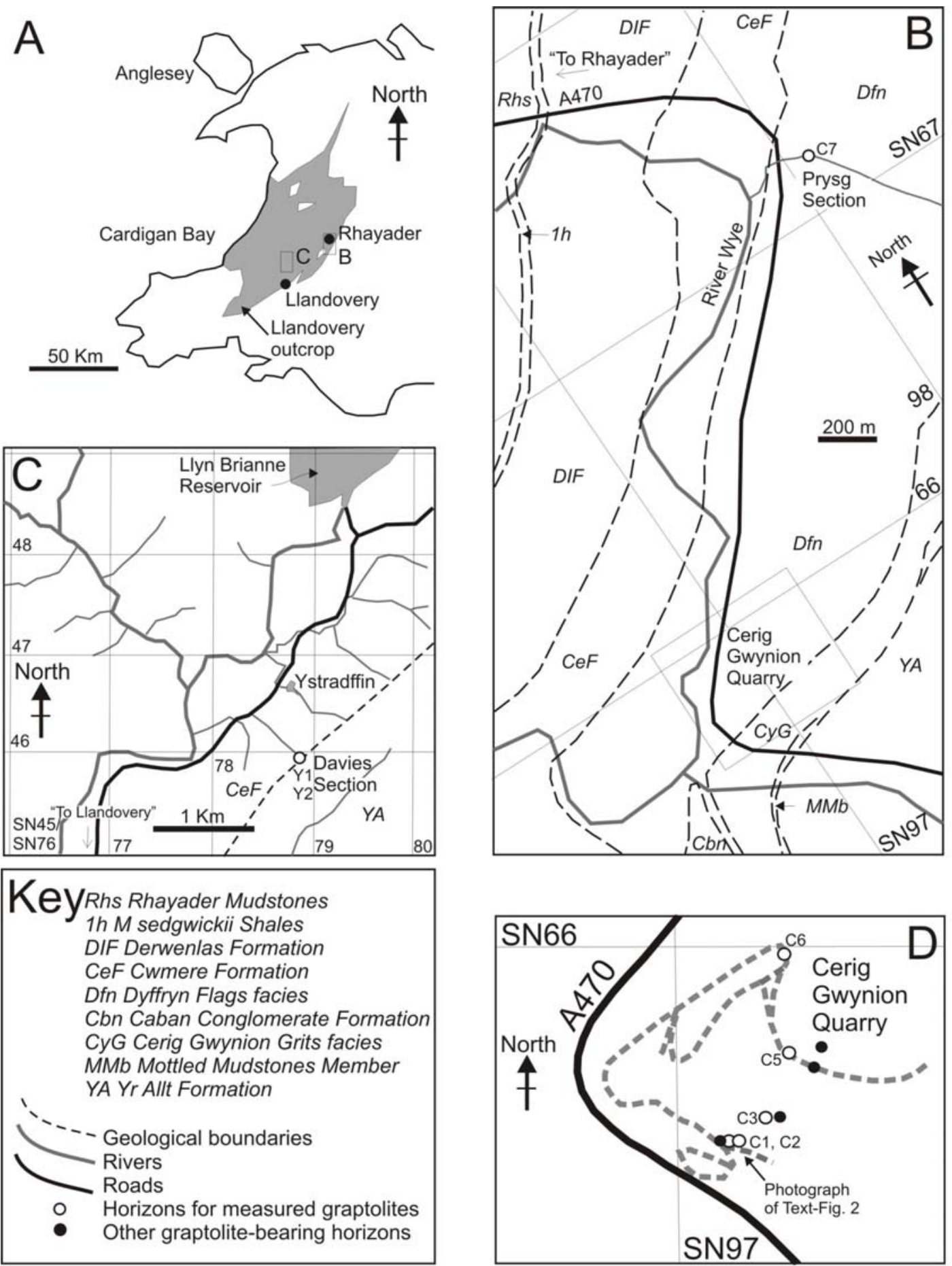

Fig. 1 

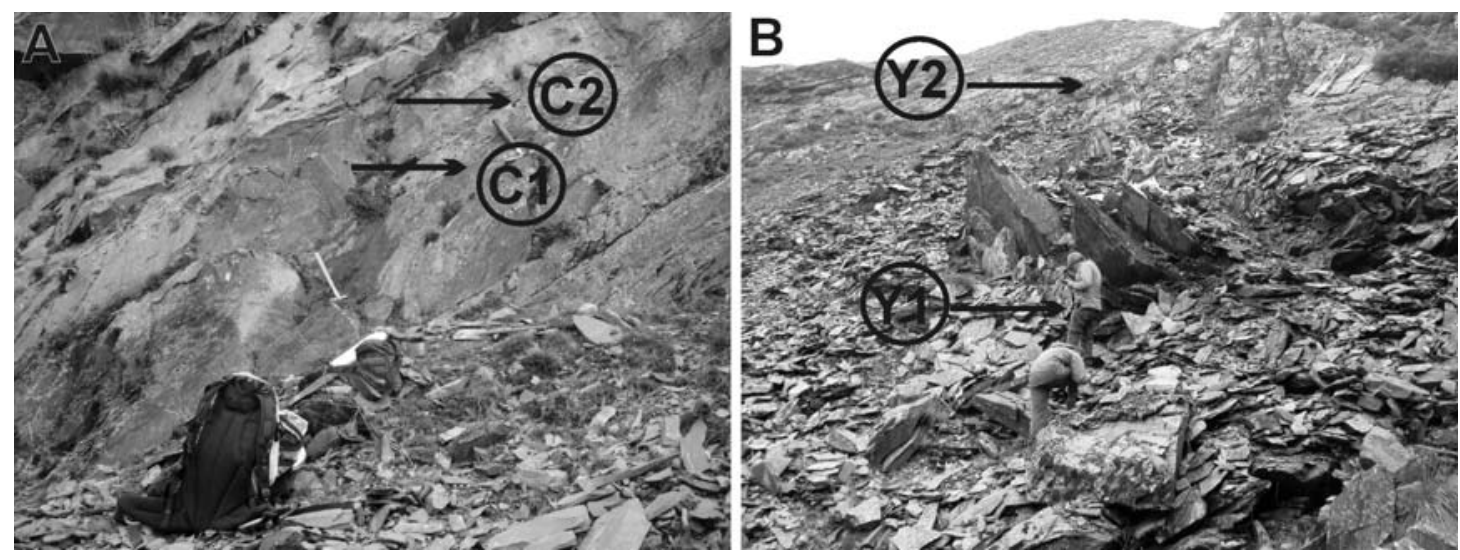

Fig. 2 


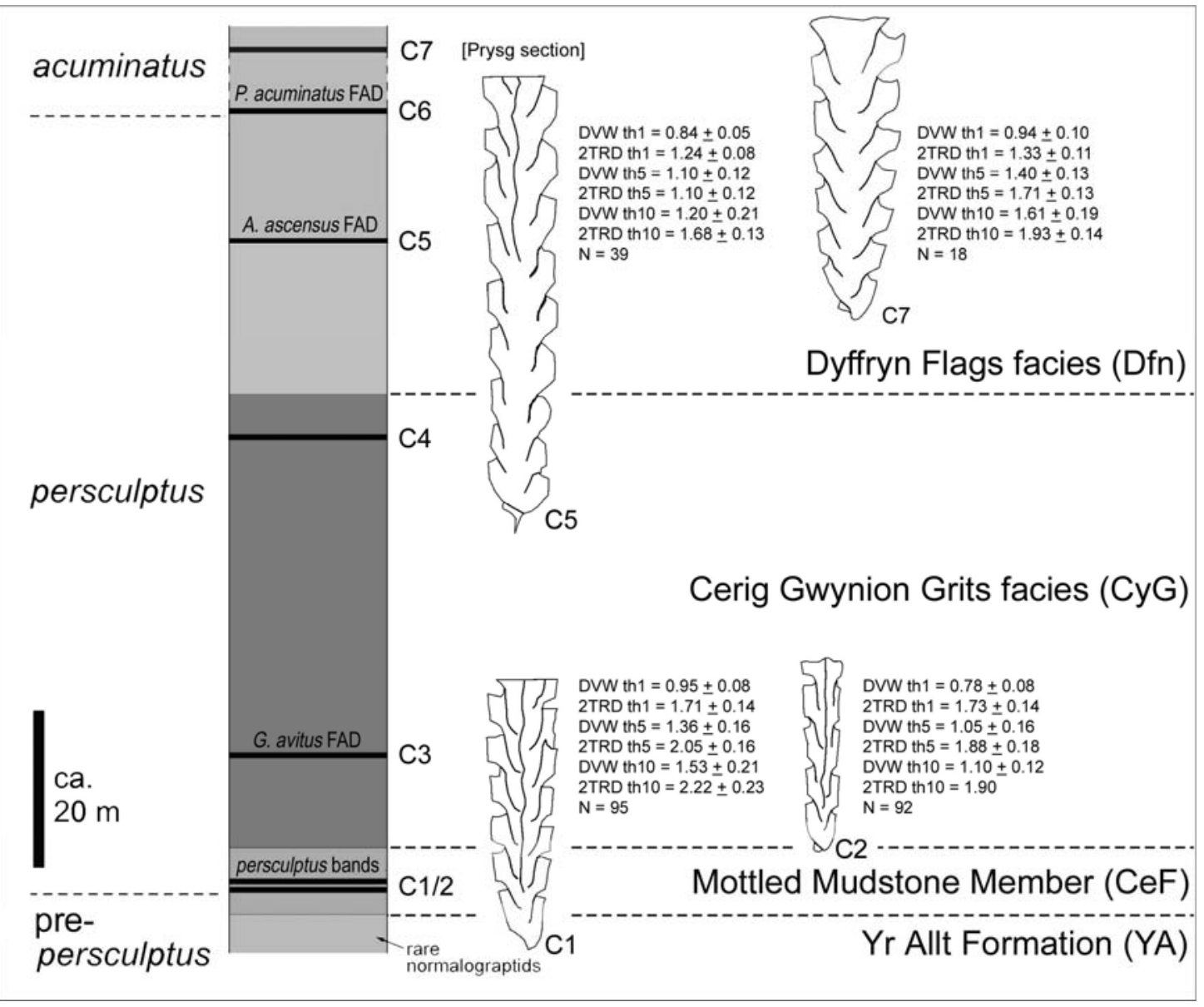

Fig. 3 

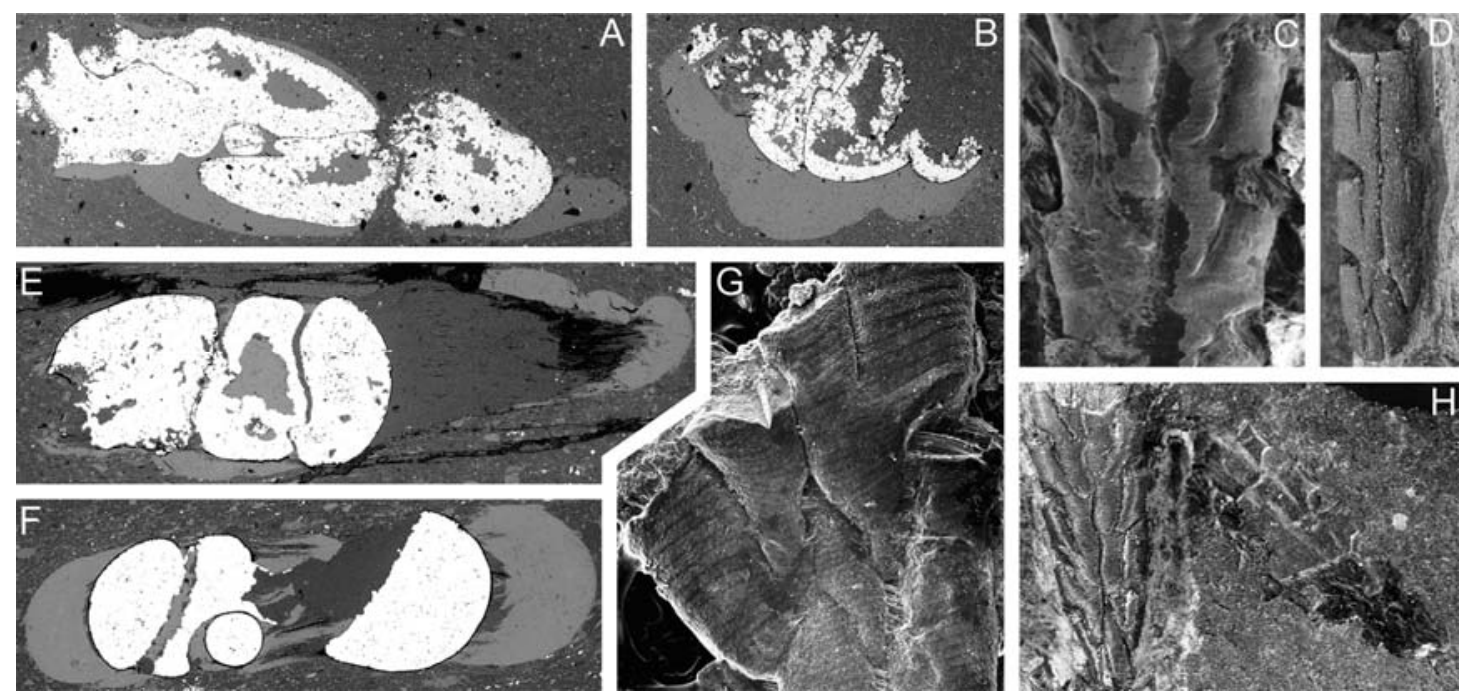

Fig. 4 


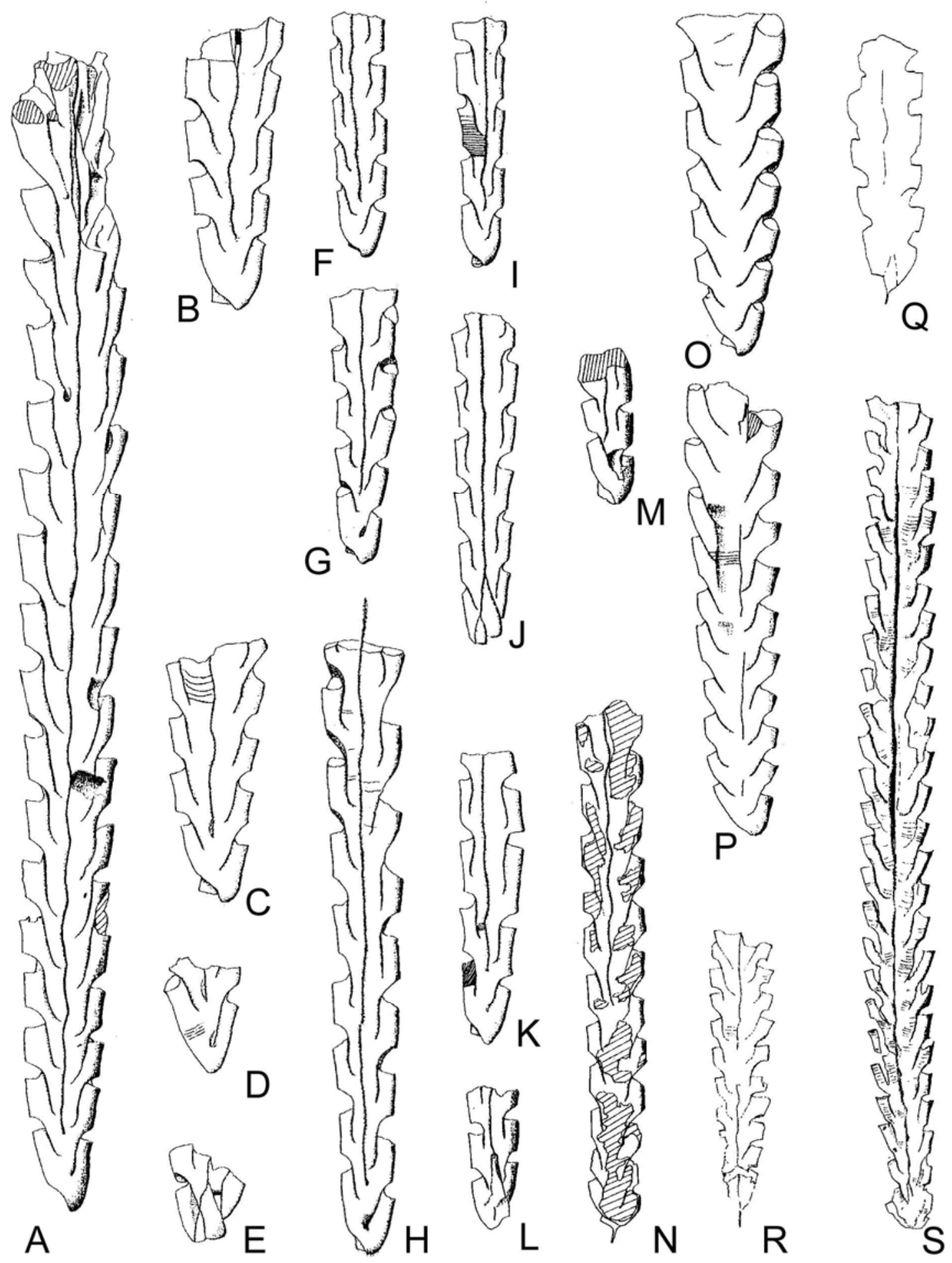

Fig. 5 

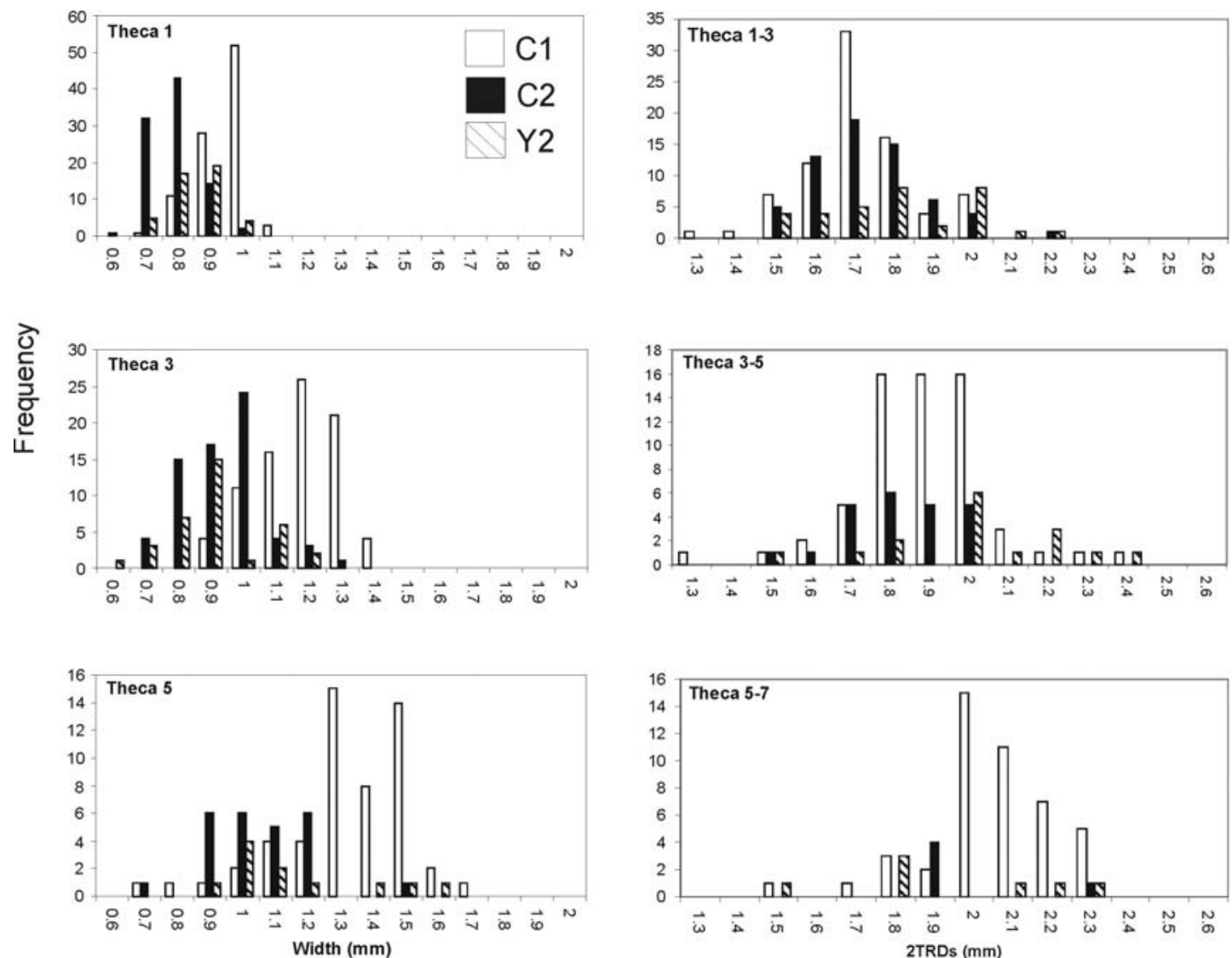

Fig. 6 
Table 1

* th2-4 ${ }^{\dagger}$ th4

\begin{tabular}{|c|c|c|c|c|c|c|c|c|c|}
\hline Taxon & Material & Locality & Biozone & $\begin{array}{l}\text { DVW } \\
\text { th1 }\end{array}$ & $\begin{array}{l}\text { 2TRD } \\
\text { th1-3 }\end{array}$ & $\begin{array}{l}\text { DVW } \\
\text { th5 }\end{array}$ & $\begin{array}{l}\text { 2TRD } \\
\text { th5-7 }\end{array}$ & $\begin{array}{l}\text { DVW } \\
\text { th10 }\end{array}$ & $\begin{array}{l}\text { 2TRD } \\
\text { th10-12 }\end{array}$ \\
\hline P. persculptus & $\begin{array}{l}\text { C1, Y1 } \\
\text { (Table 2) }\end{array}$ & $\begin{array}{l}\text { Cerig Gwynion Quarry, Rhayader, } \\
\text { and Ystraddfin, Wales. }\end{array}$ & $\begin{array}{l}\text { earliest persculptus } \\
\text { Biozone }\end{array}$ & $\begin{array}{l}0.70- \\
1.10 \mathrm{~mm}\end{array}$ & $\begin{array}{l}1.30- \\
2.00 \mathrm{~mm}\end{array}$ & $\begin{array}{l}1.00- \\
1.70 \mathrm{~mm}\end{array}$ & $\begin{array}{l}1.50- \\
2.30 \mathrm{~mm}\end{array}$ & $\begin{array}{l}1.10- \\
2.00 \mathrm{~mm}\end{array}$ & $\begin{array}{l}1.70- \\
2.60 \mathrm{~mm}\end{array}$ \\
\hline N? cf. parvulus & $\begin{array}{l}\text { C2, Y2 } \\
\text { (Table 2) }\end{array}$ & $\begin{array}{l}\text { Cerig Gwynion Quarry, Rhayader, } \\
\text { and Ystraddfin, Wales. }\end{array}$ & early persculptus Biozone & $\begin{array}{l}0.60- \\
1.00 \mathrm{~mm}\end{array}$ & $\begin{array}{l}1.50- \\
2.20 \mathrm{~mm}\end{array}$ & $\begin{array}{l}0.90- \\
1.50 \mathrm{~mm}\end{array}$ & $\begin{array}{l}1.70- \\
2.40 \mathrm{~mm}\end{array}$ & $\begin{array}{l}0.90- \\
1.20 \mathrm{~mm}\end{array}$ & $1.90 \mathrm{~mm}$ \\
\hline ?N. parvulus & $\begin{array}{l}\text { C3-6 } \\
\text { (Table 2) }\end{array}$ & $\begin{array}{l}\text { Cerig Gwynion Quarry, } \\
\text { Rhayader, Wales. }\end{array}$ & $\begin{array}{l}\text { mid persculptus Biozone - } \\
\text { early acuminatus Biozone }\end{array}$ & $\begin{array}{l}0.70- \\
1.00 \mathrm{~mm}\end{array}$ & $\begin{array}{l}1.10- \\
1.60 \mathrm{~mm}\end{array}$ & $\begin{array}{l}0.90- \\
1.40 \mathrm{~mm}\end{array}$ & $\begin{array}{l}1.40- \\
1.80 \mathrm{~mm}\end{array}$ & $\begin{array}{l}0.90- \\
1.80 \mathrm{~mm}\end{array}$ & $\begin{array}{l}1.50- \\
1.90 \mathrm{~mm}\end{array}$ \\
\hline P. persculptus? & $\begin{array}{l}\text { C7 } \\
\text { (Table 2) }\end{array}$ & $\begin{array}{l}\text { Prysg Stream section, Rhayader, } \\
\text { Wales. }\end{array}$ & mid acuminatus Biozone & $\begin{array}{l}0.80- \\
1.20 \mathrm{~mm}\end{array}$ & $\begin{array}{l}1.20- \\
1.50 \mathrm{~mm}\end{array}$ & $\begin{array}{l}1.20- \\
1.60 \mathrm{~mm}\end{array}$ & $\begin{array}{l}1.50- \\
1.90 \mathrm{~mm}\end{array}$ & $\begin{array}{l}1.40- \\
1.90 \mathrm{~mm}\end{array}$ & $\begin{array}{l}1.70- \\
2.10 \mathrm{~mm}\end{array}$ \\
\hline N? parvulus & lectotype & Gwastaden, Rhayader, Wales. & $\begin{array}{l}\text { persculptus or acuminatus } \\
\text { Biozone }\end{array}$ & $0.90 \mathrm{~mm}$ & $1.50 \mathrm{~mm}$ & ${ }^{\dagger} 1.25 \mathrm{~mm}$ & - & - & - \\
\hline P. persculptus & topotype & Ogofau, Pumpsaint, Wales. & $\begin{array}{l}\text { persculptus or acuminatus } \\
\text { Biozone }\end{array}$ & $1.40 \mathrm{~mm}$ & $1.70 \mathrm{~mm}$ & $1.90 \mathrm{~mm}$ & $1.90 \mathrm{~mm}$ & $2.0 \mathrm{~mm}$ & - \\
\hline 'N. parvulus' & $\begin{array}{l}\text { sensu } \\
\text { Loydell } \\
\text { (2007) }\end{array}$ & $\begin{array}{l}\text { United States (Loydell et al. 2002), } \\
\text { Jordan (Loydell 2007), } \\
\text { Scotland (Williams 1983). }\end{array}$ & $\begin{array}{l}\text { persculptus Biozone - } \\
\text { acuminatus Biozone }\end{array}$ & $\begin{array}{l}0.70- \\
1.00 \mathrm{~mm}\end{array}$ & $\begin{array}{l}* 1.05- \\
1.65 \mathrm{~mm}\end{array}$ & $\begin{array}{l}1.05- \\
1.60 \mathrm{~mm}\end{array}$ & $\begin{array}{l}1.20- \\
1.80 \mathrm{~mm}\end{array}$ & $\begin{array}{l}1.25- \\
1.70 \mathrm{~mm}\end{array}$ & $\begin{array}{l}1.15- \\
1.75 \mathrm{~mm}\end{array}$ \\
\hline 'N. persculptus' & $\begin{array}{l}\text { sensu } \\
\text { Loydell } \\
\text { (2007) }\end{array}$ & $\begin{array}{l}\text { Kazakhstan (Koren' et al. 1980), } \\
\text { Wales \& Bohemia (Štorch \& } \\
\text { Loydell 1996). }\end{array}$ & persculptus Biozone & $\begin{array}{l}0.85- \\
1.15 \mathrm{~mm}\end{array}$ & $\begin{array}{l}1.25- \\
1.70 \mathrm{~mm}\end{array}$ & $\begin{array}{l}1.05- \\
1.60 \mathrm{~mm}\end{array}$ & $\begin{array}{l}1.25- \\
2.10 \mathrm{~mm}\end{array}$ & $\begin{array}{l}1.40- \\
2.25 \mathrm{~mm}\end{array}$ & $\begin{array}{l}1.80- \\
2.30 \mathrm{~mm}\end{array}$ \\
\hline
\end{tabular}


Table 2

\begin{tabular}{|c|c|c|c|}
\hline $\begin{array}{l}\text { C1- Cerig } \\
\text { Gwynion }\end{array}$ & \multicolumn{3}{|c|}{$\begin{array}{l}\text { EJB 194, EJB 198, EJB 198a, EJB 199, EJB 199b, EJB 199d, EJB 201, EJB 203, EJB 205, EJB 208, EJB 213, EJB 215, EJB } \\
217 f, \text { EJB 223, EJB 230,EJB 233, EJB 233a,EJB 237, EJB 238, EJB 240f, EJB 242, EJB 246, EJB 247, EJB 252, EJB 255, EJB } \\
270, \text { EJB 273, EJB 274, EJB 275, EJB 275a, EJB 275c, EJB 279, EJB 280, EJB 284, EJB 288, EJB 289, EJB 290, EJB 293, } \\
\text { EJB 299, EJB 310, EJB 311, EJB 321, EJB 322, EJB 329, 333, EJB 349, EJB 350, EJB 351, EJB 356, EJB 362, EJB 362a, } \\
\text { EJB 364, EJB 368, EJB 373, EJB 373a, EJB 375, EJB 376, EJB 378, EJB 379, EJB 383, EJB 383a, EJB 383b, EJB 384, EJB } \\
\text { 389, EJB 392, EJB 393, EJB 394, EJB 394a, EJB 398, EJB 400, EJB 408a, EJB 412, EJB 420, EJB 421, EJB 421a, EJB 431, } \\
\text { EJB 432, EJB 437, EJB 438, EJB 439, EJB 440, EJB 444, EJB 450, EJB 450a, EJB 451, EJB 452, EJB 462, EJB 463, EJB } \\
\text { 468b. }\end{array}$} \\
\hline & \multicolumn{3}{|c|}{$\begin{array}{l}\text { EJB 488, EJB 490, EJB 475, EJB 477, EJB 476a, EJB 476b, EJB 478, EJB 480, EJB 480a, EJB 481, EJB 484, EJB 491, EJB } \\
\text { 494, EJB 496, EJB 494, EJB 497, EJB 505, EJB 504, EJB 503, EJB 502, EJB 506, EJB 507, EJB 510, EJB 514, EJB 514a, } \\
\text { EJB 515, EJB 515b, EJB 518, EJB 518a, EJB 519, EJB 520, EJB 521, EJB 522, EJB 522a, EJB 522b, EJB 523, EJB 524, EJB } \\
\text { 524a, EJB 529, EJB 534, EJB 533, EJB 536, EJB 543, EJB 552, EJB 548, EJB 554, EJB 556, EJB 556a, EJB 559 EJB 562a, } \\
\text { EJB 556, EJB 64, EJB 567, EJB 569, EJB 573, EJB 578, EJB 581, EJB 582, EJB 582a, EJB 585, EJB 586, EJB 586a, EJB } \\
\text { 589, EJJ 589a, EJB 589b, EJJ 602, EJB 607, EJB 616, EJB 619, EJB 625, EJB 626, EJB 628, EJB 630, EJB 633. JZ 4851, JZ } \\
\text { 4851a, JZ 4852, JZ 4855, JZ 4857, JZ 4858, JZ 4859, JZ 4861, JZ 4867, JZ 4867b, JZ 4872a, JZ 4872b, JZ 4874, JZ 4875a, } \\
\text { JZ 4877, JZ 4878, JZ 4888, JZ 4888b, JZ 4890, JZ 4891, JZ 4887. }\end{array}$} \\
\hline & & & C7-Prysg \\
\hline & \multirow{2}{*}{$\begin{array}{l}\text { EJB 641, EJB 642, EJB 642a, EJB 643, EJB 643a, EJB 644, } \\
\text { EJB 645, EJB 646, EJB 646a, EJB 646b, EJB 647, EJB 649, } \\
\text { EJB 650, EJB 657, EJB 658, EJB 659, EJB 659a, EJB 662, } \\
\text { EJB 664, EJB 665, EJB 671, EJB 671a. JZ 4761, JZ 4762, JZ } \\
\text { 4765, JZ 4766, JZ 4766a, JZ 4767, JZ 4768, JZ 4769, JZ } \\
\text { 4772, JZ 4779, JZ 4781, JZ 4782, JZ 4784, JZ 4802, JZ 4803, } \\
\text { JZ 4817c, JZ 4828. }\end{array}$} & \multirow{2}{*}{$\begin{array}{l}\text { JZ 4833, JZ } \\
4834, \text { JZ } 4837 \\
\text { JZ } 4838, \text { JZ } \\
4838 b, J Z \\
4838 c, J Z 4847 .\end{array}$} & \multirow{2}{*}{$\begin{array}{l}\text { DJ 8799a, DJ 8799b, DJ 8799c, DJ } \\
\text { 8821/22, DJ 8807, DJ 8812, DJ 8815, DJ } \\
\text { 8818, DJ 8826, DJ 8829b, DJ 8829c. EJB } \\
\text { 415, EJB 416, EJB 417a, EJB 417b, EJB } \\
\text { 417c, EJB 417d, EJB 417e. }\end{array}$} \\
\hline & & & \\
\hline $\mathrm{Y} 1$ & \multicolumn{3}{|c|}{$\begin{array}{l}\text { EJB 921a, EJB 921b, EJB 923, EJB 926, EJB 932a, EJB 932b, EJB 934, EJB 935, EJB 936, EJB 938a, EJB 940, EJB 941, } \\
\text { EJB 942, EJB 943, EJB 944, EJB 946, EJB 948, EJB 949a, EJB 949b, EJB 949c, EJB 950, EJB 951, EJB 953a, EJB 953b, } \\
\text { EJB 953c, EJB 953d, EJB 955, EJB 956, EJB 956a, EJB 956b, EJB 958, EJB 961, EJB 962, EJB 963, EJB 963a, EJB 964, } \\
\text { EJB 968. }\end{array}$} \\
\hline Y2- Ys & \multicolumn{3}{|c|}{$\begin{array}{l}\text { EJB 1, EJB 6, EJB 13, EJB 18, EJB 19, EJB 24, EJB 28b, EJB 29, EJB 30, EJB 42, EJB 45, EJB 58, EJB 65, EJB 68, EJB } \\
\text { 74, EJB 97, EJB 101, EJB 107, EJB 110, EJB 116, EJB 123, EJB 124, EJB 125, EJB 129a, EJB 129c, EJB 139, EJB 142a, } \\
\text { EJB 142, EJB 147, EJB 148, EJB 148A, EJB 149, EJB 175, EJB 180. }\end{array}$} \\
\hline
\end{tabular}


